\title{
The power and perils of participant observation in library and information science research: reflections on three South African studies
}

\author{
Genevieve Hart
}

\begin{abstract}
This article reports on three participant observation studies conducted in schools and libraries in South Africa, between 1999 and 2015. The study findings have been reported on elsewhere, thus the focus is on the methodologies used, with the common thread being the author's preoccupation with the information literacy education of South African pupils. The author's purpose was to provide evidence of the impact of the dire lack of resources and libraries at South African schools. The first study in 1999 explored how teachers at an underresourced primary school in Cape Town, western cape, were coping with the demands of the new curriculum. The second study in 2006 examined two public libraries in a rural town in Mpumalanga, with seven local schools, but no school libraries. The third study in 2015 involved the library at a high school in Kayelitsha Township outside Cape Town, which is part of a non-governmental organisation (NGo) project to employ school leavers to manage school libraries. Participant observation is rare in the Library and Information Science (LIS) research literature and the author's aim is to demonstrate its power to dig beneath the surface. The article uncovers the complex relations and tacit beliefs that existed at the three research sites, which are probably at play in other contexts and which have to be taken into account in planning effective programmes in South African schools and libraries. The article also acknowledges the ethical challenges, arguably inherent in participant observation, which relate to the often sensitive relations among participants, and to the researcher's positioning.
\end{abstract}

\section{Introduction}

This article ${ }^{1}$ reflects on three participant observation studies in schools and libraries in South Africa, between 1999 and 2015. Their common thread is my interest in the information literacy education of South African school learners, given the documented uneven access to school libraries, whose central business worldwide is deemed to be information literacy. My research purpose over the years has been to examine the impact of the shortage of libraries on the preparedness of South African youth for their post-school lives - in higher education, the workplace, and civic society. Together, the three studies

\footnotetext{
${ }^{1}$ This article is based on an unpublished presentation given at the 8th Qualitative and Quantitative Methods in Libraries International Conference, London, May 24-27, 2016.
} 
described in the article show how deeply held beliefs about libraries and conceptions of their social role might explain the gaps between the lip-service paid to the importance of libraries and behaviours on the ground. In keeping with one of the principles of interpretive research, the interplay of observations and iterative interviewing enabled the researcher to dig beneath the surface (Klein and Myers 1999, 77). The focus in the article is not on the findings of the three research projects, which have been reported on in Hart (1999, 2004, 2006a, 2006b, 2015), but on the methodologies used.

Participant observation has its roots in anthropological ethnography - and indeed the term is often used interchangeably with ethnography (Berg 2007, 171). Its intention is to examine and represent a situation from insiders' perspectives through immersion or "soaking" in it (Berg 2007, 172). A later section will describe the wide range of data gathering methods used in participant observation. In their outline of ethnographic research in North American libraries, Pashia and Critten $(2015,87)$ argue that its most common application has been to gather information on how people use and experience libraries in order to improve the services offered. The focus in this article is not library users but rather what the studies revealed about the perspectives and underlying beliefs of the role-players at the three research sites.

A perusal of Library and Information Science (LIS) journals reveals how rare participant observation or ethnography is in South African LIS research. The purpose in the article is to demonstrate its value over the case studies which, on the basis of a visit and once-off interviews, make definitive conclusions about a site and its participants. The argument is that the long-term engagement in a site allows the researcher to explore its "complex interactions, tacit processes and hidden beliefs and values" (Marshall and Rossman 1995, 9). However, the article also acknowledges that it brings practical and ethical challenges. Its open-endedness, what Creswell $(2007,37)$ calls its "emerging approach", entails certain risks or perils. Unexpected themes and findings might emerge which call into question the researcher's preconceptions and which might affect delicate relationships among participants.

\section{Background to the three studies: school libraries in South Africa}

Some preliminary information on the context of the three studies is needed in order to make sense of the discussion of the methodologies used that follows. The post-apartheid curriculum introduced in 1997, Curriculum 2005 (DoE 1997), and its revision in 2001, the Revised National Curriculum Statement (DoE 2001) seemed to offer a new climate for school libraries (Zinn 2002). Another revision, the Curriculum and Assessment Policy Statement (DBE 2012) came after recognition of the widespread failure of the first two attempts. All three might be described as "library friendly" for two reasons: they recognise the ability to "collect, analyse, organise and critically evaluate information" as a generic cross-curricular outcome (DBE 2017); and their documentation promises an ethos that values critical thinking and active discovery learning. Librarians might assume that their emphasis on assessing learning by means of independent projects and portfolios of work opens the way for resource-based and enquiry learning. The Department of Education (DoE) itself seemed to 
share this assumption, as De Vries $(2002,10)$ points out in his quotation from a 1997 DoE publication explaining Curriculum 2005 to teachers, which stated that "adequate resources [for the new outcomes-based approaches] are essential" and that "adequate provisioning of libraries" was being accelerated.

Redress of the disparities of apartheid has been claimed to be a central principle of South African educational reforms since 1994. But audits of school facilities, such as those given in the reports of the DBE's National Education Infrastructure Management System (NEIMS), have quantified the ongoing dire lack of learning resources in most South African schools. On the whole, it is still true that only the historically advantaged suburban schools have functional libraries, which are funded by the fees they charge to supplement their government allocations, and which arguably contribute to their superior academic performance. Thanks to pressures from the civic society activist group, Equal Education, and also from the advisory body to government, the National Council for Library and Information Services (NCLIS), there has been some progress towards redressing the inequities (Hart and Zinn 2015). Thus, Equal Education's legal action against the DBE in 2012 led to the long-overdue publishing of regulations on norms and standards for school infrastructure. They state that "every school must have a school library or media center" and "a minimum adequate and suitable collection" (DBE 2013, 16). However, so far, no clear strategy has emerged from government that might translate such rhetoric into reality on the ground - although it has to be said that NCLIS has declared its intention to pursue the prioritisation of school library policy as recommended in the LIS Transformation Charter (DAC and NCLIS 2014).

Some years ago, the situation of school libraries in South Africa was labelled as a "conundrum" (Hart and Zinn 2007, 89). Given the national imperative to redress the apartheid era unequal distribution of resources across advantaged and disadvantaged school sectors, as well as the resource-thirsty curricular reforms since 1997 described in the above paragraph, the reluctance of educationists and policy-makers to tackle the huge school library backlogs is hard to explain. The three participant observation studies described in the article set out to explore the conundrum. It was hoped that participating in the life of the chosen sites, rather than surveys or dropping in for once-off interviews, would serve to build insight into their worlds and realities.

\section{The principles of participant observation}

Creswell's $(2007,37)$ definition of qualitative research provides a useful summary of the key attributes of participant observation:

Qualitative research begins with assumptions, a world view, the possible use of a theoretical lens, and the study of research problems inquiring into the meaning individuals or groups ascribe to a social or human problem. To study this problem, qualitative researchers use an emerging qualitative approach to enquiry, the collection of data in a natural setting sensitive to the people and places under study, and data analysis that is inductive and establishes patterns or themes. 
Qualitative research is often described as "naturalistic" and "interpretive". The qualitative researcher immerses herself in the context under study in order to understand it as an insider. Although there is acknowledgement that the presence of an outsider within a social setting must always have some impact, the aim in naturalistic research is to examine the specific social context "as it is". The aim of a qualitative field study is not merely to observe and record but to "interpret" (Stake 1995, 9). The researcher is placed in the field as an interpreter to observe the workings of the case; to record objectively what is happening; and at the same time, to examine its meanings. The initial questions are informed by knowledge of existing theory and research and by the purpose of the research. But the examination of meaning is progressive - as new issues crop up, questions are discarded and new ones introduced. Meaning-making thus has to change direction, accept modifications and refinements - in the course of the study (Stake 1995, 9).

Wolcott (1992, 9), a leading authority on ethnography from which participant observation has evolved, summarises its data gathering as experiencing (watching and listening), enquiring (interviewing), and examining (studying materials prepared by others). Wolcott $(1994,12)$ identifies the three tasks of an ethnographic account as:

- description, which addresses the question, "What is going on here?" Data consist of observations made by the researcher and/or reported to the researcher by others;

- analysis, which addresses the identification of essential features and the systematic description of interrelationships among them - in short how things work or not work;

- interpretation, which addresses questions of meanings and contexts such as, "What is to be made of it all?"

Klein and Myers' (1999, 77) discussion of the principles of interpretive research in conducting research in information systems offers a useful framework for the three studies at libraries:

- The overarching principle of the hermeneutic circle means that an understanding of a whole comes from an understanding of its parts and of how they interrelate with one another and with the whole. The iterative process will ensure that the "big picture" is constructed from the issues and themes that emerge from the data gathering.

- Contextualisation requires that any research must be grounded in its context; without this, the understanding of what is happening will be limited.

- Researcher reflexivity notes that the research does not only have an impact on the research subjects, causing them to see events from an outsider's perspective: it also has an impact on the researcher. The researcher must be prepared to have his or her preconceived notions challenged in the course of the project.

- The openness to multiple interpretations implies that it is quite possible for two different interviewees to have different perceptions about the same event, given their personal histories, and that neither should be considered incorrect. 
- Suspicion or scepticism means that researchers should constantly look beyond the obvious surface detail, and dig deeper to discover the power structures and possible inequalities.

The research method of participant observation can be seen as a continuum with participation and observation as its two poles. Figure 1 reproduces Guest, Namey and Mitchell's (2012, 89) diagram of the continuums in participant observation and its diverse data-gathering methodologies.

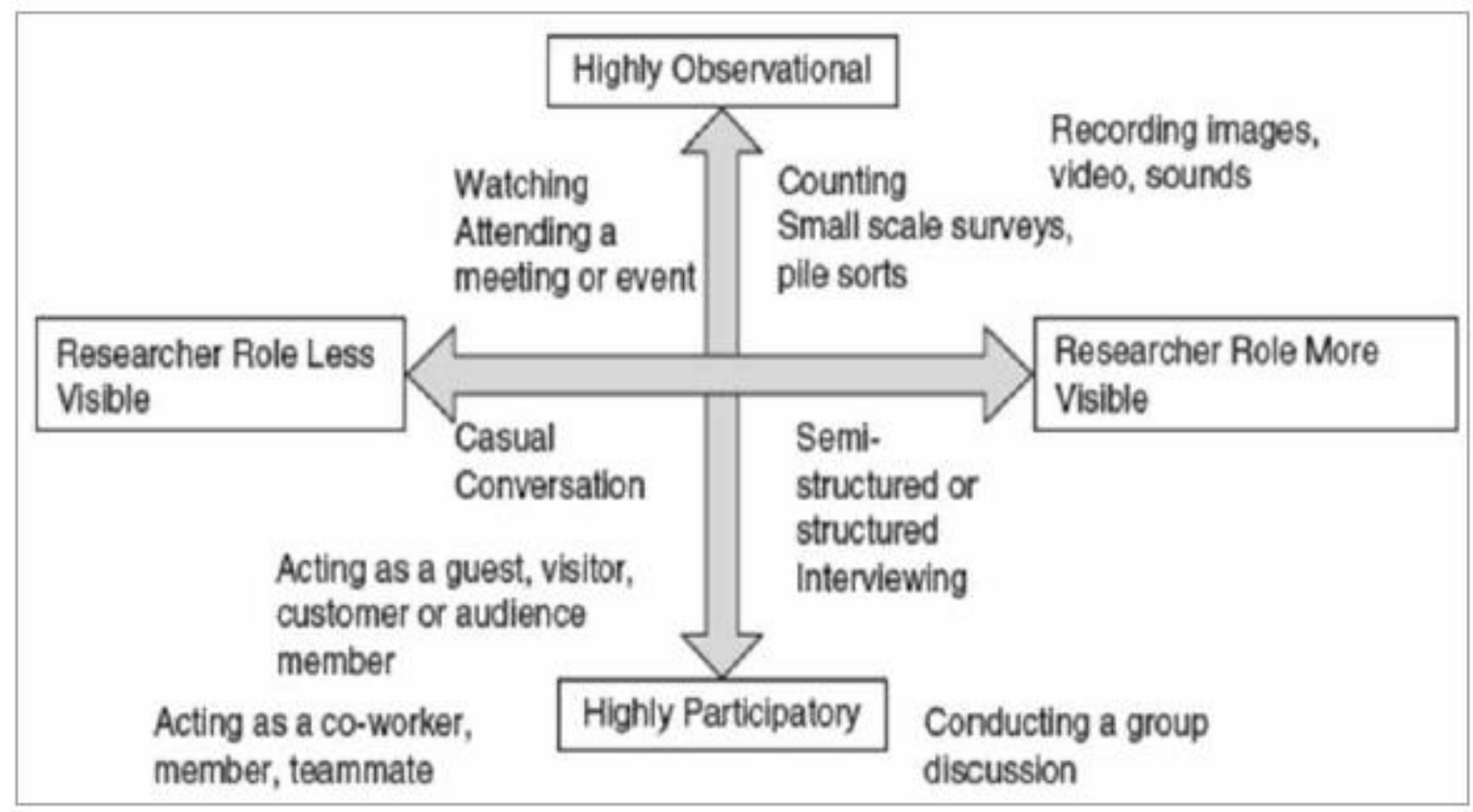

Figure 1: Participant observation continuums (Guest, Namey, and Mitchell 2012, 89)

Each of the three studies described in the article had a different weighting of participation and observation and all three employed a mix of the methods shown in Figure 1.

\section{Thethreestudies}

The article provides just a glimpse of the three studies, extracting only a few strands from the mounds of data in order to illustrate some of the principles of interpretive research listed above. As stated in the introduction, they have been written up more fully in earlier publications. The three accounts in the current article return to the primary data collected in the course of the studies. Each of the three accounts has its own focus as shown in their distinctive section headings. The thread connecting the three studies is my preoccupation with the information literacy education of South African pupils. In accordance with promises of anonymity, all the names of places and people are pseudonyms.

The first study to be described set out to explore how teachers at Galant Primary School, an under-resourced primary school in Cape Town, Western Cape, were coping with the demands of the new resource-based curriculum, introduced in 1997, and with its ubiquitous project work. The second study took place in 2006 in a rural town, Woodsville, in 
Mpumalanga. It set out to examine how the town's two public libraries were connecting to the seven local schools, none of which had a library. The third study in 2015 was conducted at the library at NSS High School, in Khayelitsha, a sprawling township on the outskirts of Cape Town. The library belongs to a project that provides stipends for young unemployed school leavers to act as library managers at about 40 disadvantaged schools. My underlying purpose was to examine the potential of this approach as a solution to the human resources challenges that clearly will confront any future effort to build a school library system across the country.

\section{Galant primary school study: context and teachers' scripts}

The significance of the geography of Galant Primary School (hereafter Galant), situated in a corner of a township surrounded by major highways and a railway line, became apparent as the field study progressed. The Galant children are cut off from the city by more than their site. Poverty and high crime rates were found to pervade every aspect of school life with more than 60 per cent of the parents unemployed and dependent on government family grants. The sandwiches distributed throughout the school each morning are essential as teachers believe that hunger causes some of the inattentiveness among their pupils. At times teachers would emphasise the special closeness of the community, describing it as an enclave; at other times its more negative ghetto-like qualities would come to the fore. $\mathrm{Mr}$ Moosa, the deputy principal, told me that his pupils knew nothing about the world outside the township; and, according to Mr Mitchell, the Grade 3 teacher, few of the children ever went further than the shopping centre in the next suburb.

The Galant study belongs to the sub-genre of classroom ethnography. Delamont and Hamilton $(1984,18)$ contrast the closed approach of systematic classroom observation with the open-endedness of the participant observation techniques of classroom ethnography. They argue that its mix of long-term observation, structured and unstructured interviewing, together with its holistic approach, make participant observation a powerful tool for classroom research. The Galant study involved many hours of my sitting at the back of a Grade 7 classroom, watching as groups were undertaking a science and a history project. As Berg $(2007,186)$ points out, the ethnographic researcher aims to become "invisible" and, indeed, as Berg observes, after a few days the children grew used to my presence and lost interest in what I was doing. The left-hand back corner close to me was always occupied by an unstable pool of boys whom I came to label "the lost ones". They seemed alienated from the day-to-day activity of the class, arriving late, if at all. Teachers tended to ignore them as long as they caused no trouble. They did not work cohesively as a group, preferring to drop in on other groups to find answers for their work-sheets. My plan at the start was to focus exclusively on the Grade 7 project work; but, in keeping with the open-endedness of qualitative research, I soon widened my gaze to include the Grade 1 and 4 classes as the Grade 7 teachers often complained to me that their pupils could not do project work because they had not been taught to read earlier.

My observations of the gaps between what I was seeing in the Grade 7 group work and what the teachers were telling me in their interviews soon alerted me to the need for researcher 
reflexivity. I had gained entry to the school with the promise that I would be looking at how teachers were managing the emphasis on project work in the new curriculum. I arrived at the school looking forward to seeing progressive teachers at work. In my preliminary interviews, they showed an awareness of the key concepts in Curriculum 2005 ${ }^{2}$ with $\mathrm{Mr}$ Moosa saying: "OBE [outcomes-based education] - we are already doing it."

However, in the next few weeks my conceptions shifted. The posters and pamphlets for example, which the science teacher had gathered for her project, lay for weeks at the front of the classroom with the teacher making no attempt to mediate their use. She referred to them in an interview, saying:

These beautiful transparencies that the school bought and nobody came to ask for that. Most of the animals are on them, but nobody came. And I am not going to just give it to them [without their asking for it]. And they should have come to me say after school or whenever I am free, come and ask me you know. Nobody came to ask. So I thought well maybe they know what they are doing ... I gave them that bit of freedom, by not keeping tabs on them all the time ... Just to see what's in them, what can I get out of them.

Already on the first day, I had noted a certain ambivalence about the new curriculum, Curriculum 2005, in my interviews with the teachers. For example, one asserted: "Bengu [the then Minister of Education] doesn't know what it's like" - referring to large classes, shortage of resources and also to "our kind of children". Well into the study, one of the Grade 7 teachers told me:

Forget what you have been taught at college and take the child the way he is now ... Our kind of children don't need it [author's emphasis]. Maybe it will work in a more affluent school but not here in our townships. Children from townships are different - you can't get away from it.

The reference to "our kind of children" became familiar in the following weeks and the phrase soon became a unit of meaning or theme in my on-going data analysis. Another theme that surfaced was the conception of information as something teachers had to give their pupils, then "get out" from them. Both of these two themes can be seen in these words from a Grade 7 teacher:

You have to give them a lot of info first, especially our kids. Because our kids are located in this area where there is actually no information ... So that when we want something from them, we can know that we are going to get something out, because you have given them information, you know ...

\footnotetext{
2 Curriculum 2005 (DoE 1997) was described as "outcomes based" as it emphasised learning outcomes rather than teachers' objectives. See the earlier discussion of the post-apartheid attempts to transform the South African school curriculum.
} 
There is insufficient space here to provide more of the data analysis. My purpose in this article is to show how the combination of iterative interviewing and relatively long- term observation uncovered deeply held beliefs and scripts that I found were filtering teachers' responses to the demands of the new curriculum, encapsulated in the following refrains:

- "We know our people."

- "We have to give it all here."

- "We're already doing it."

The data analysis and findings of the Galant study are reported more fully in an earlier article (Hart 1999).

\section{Woodsville public libraries study: different "truths" and power relations}

In common with most South African rural towns, Woodsville, the site of the second study, still reflects the town planning of the apartheid era - as do its libraries. Woodsville Library is downtown, just off the high-street; and the other is in Hillside, the so-called black township on its outskirts. After a survey of all the public libraries in its province (Hart 2006b), I chose Woodsville for a six-week long participant observation study in its two libraries (Hart 2006a), as I had been impressed by the two library managers' accounts of their work with the surrounding schools.

The third day of my visit brought the incident that was to frame my six-week long investigation. I was invited to sit in on a library workshop for a school to be run by both librarians at the Hillside library. However, the pupils did not arrive at the appointed time and Naledi Matolo, the Hillside librarian, went up to the school to fetch them. Here follows an extract from the vignette I wrote describing the incident, which has been covered in more detail in Hart (2004, 215). According to Stake (1995, 128), vignettes are "briefly described episodes to illustrate key aspects of the case". They are useful in structuring qualitative case study reports as they condense observations and point to lines of enquiry:

At last, I see Naledi Matolo picking her way through the crowds. Her shoulders are slumped and, as she reaches Tara Botha [the Woodsville library manager], she says bluntly, "They are not coming. The teachers don't want them to come now." Tara's face freezes but she says only, "It's very disappointing. It's very disappointing." I tell Naledi that I am going to the school to introduce myself to the principal and to make appointments for interviews. I refuse her offer to come with me. The previous day's doubts have resurfaced and I wish to be seen as independent of the two librarians. (Hart 2004, 215)

Over the next few days, I chatted with both librarians to explore their thoughts on the failure of the workshop and I interviewed the teacher at the school whose pupils had been expected. Then the following week I brought it up in more formal interviews with the two librarians. My purpose here is to show their different perspectives and also the power of 
iterative interviewing over once-off interviews. The day after the incident both librarians laid the blame on the teachers:

The problem lies with the teachers. They don't use the library so they don't see the importance for the kids. Even if you sacrifice and say I'll come and fetch them it becomes difficult. You find you don't get the agreement. (Naledi Matolo) Don't they [the teachers] know how important it is? (Tara Botha)

But in an interview some days later, Tara Botha seemed to lay the blame on her colleague at Hillside, saying: "I think she [Naledi Matolo] didn't want to [have the workshop]. I'm not getting anything from her."

But then a few minutes later, another possibility emerged when, thinking of the rigid rules on children leaving school premises in my own province, I asked her how she had arranged the visit to the library with the school and learned that perhaps she had assumed too much.

Author: Can you just take classes out of school?

Tara Botha: We never have that problem. They just walk down. I always speak to the principal.

Author: Did you speak to the Hillside principal this time?

Tara Botha: No.

In the meantime, the Hillside teacher had given me his explanation as to why he had not sent his pupils to the library. In this extract from our interview he betrayed a certain distrust of the Hillside librarian as a teaching colleague:

I don't think it's wise to send them over there without you every time. First I think, number one, the lady over there needed to have a particular partner in the school to work with. I don't think the people working over there in the library - they shouldn't just sit back and expect the, especially the young learners, to use the library. I think learners should know - if the teacher is not there, they do have someone there who is acting as the teacher.

Later on he was critical of the inadequacies of the Hillside library, saying he preferred to use the down-town library:

I go to the library in town because it's better than this one ... It's got more books. There is here [sic]. They don't buy any new books. I already know there won't be anything. So why bother?

Naledi Matolo, the Hillside librarian, would probably agree with his assessment of her library. In an interview, she revealed her unhappiness, claiming that it was not her fault that her library was underused and that she had been unfairly overlooked: 
... the community, it's just they are reluctant. They don't want to use the library ... Here I am just sitting. It's quiet. They don't use the library so you don't develop that much ... It's a situation I can't change.

I find it unfair. Because my colleagues who are in charge of a library like in Woodsville they were changed to a better level. Why not me? ... Is it because I'm ... at the township? Or because my library's not busy. That's not my fault ...

Fuller reports of the Woodsville public libraries research project have been published in Hart (2006a, 2006b).

\section{NSS high school library study: revelations on status}

The third study was conducted in 2015 at the NSS High School (hereafter NSS) library in the sprawling township of Khayelitsha on the outskirts of Cape Town. The library is one of the 40 libraries of the so-called Bringing Life to School Libraries Project of the non- governmental organisation (NGO), The Bookery which raises funds for unemployed school leavers to manage the libraries which it sets up. NSS was chosen for the study as, unlike the other schools, it had a qualified school librarian on its staff, Thandi Sibandla, who however was a full-time senior English teacher with only a few "free" periods a week to drop into the library. Lindi Maropa was the library assistant provided by The Bookery. I went into the school hoping to explore the working relationship between these two women, wondering what might be learned from The Bookery project for school library development in South Africa, given the virtual non-existence of professional posts for librarians in our public schools.

The NSS library is an impressive well-organised space, which, before The Bookery intervention in 2010, had fallen into disarray as it had never had a full-time staff member. However, within a day or two of my stay at the library, questions arose as to why it was so empty for most of the teaching day. At intervals and after school it was fairly busy with students doing their homework and borrowing books. But in the course of the first week of my study only two teachers brought their classes into the library to work on an assignment. Lindi Maropa spent much of her morning in an empty room. In the course of the study, as far as I could see, she was never invited into the teachers' staff room or to their meetings. Early on she revealed her sense of isolation in this telling sentence: "It's quite lonely. It's almost like you're a bit of an outsider." Her words came to frame my investigation in the following weeks. As in all participant observation research, I soon was gathering mountains of data; but the focus here is on what the observation at the library, the iterative interviewing, and a questionnaire survey of the teachers revealed about the observed underuse of the library and the status of Lindi Maropa.

A short questionnaire was a convenient tool to explore the teachers'attitudes towards the library. Only 16 of the school's 35 teachers chose to complete the questionnaire -13 of them claiming to have supported the revival of the library in 2010. Bias in favour of the library in the analysis of the questionnaires is thus likely. On being asked why they supported the 
revival of the library, several referred to the need to improve the reading culture of the school and several talked of access to resources. The issue of resources was returned to frequently in answers to later questions. Three made the point that their learners had no other resources - with one saying: "Most of our learners are from disadvantaged communities (informal settlements); our library is the best place for them to do their school work."

The concern over low literacy was evident in the finding in the next question where almost unanimously the respondents rated the learners' literacy abilities as "weak". Despite their claims of the value of a library in a school and in their teaching, only three respondents reported that they had brought a class to the library more than four times so far that year and eight said they have not brought a class at all. On being asked how the library could be improved, two responses dominated:

- The need for more resources and for more up-to-date resources: My own investigation of the contents of the shelves confirmed the need for more appropriate and curriculum-related materials.

- Access to the internet: The library's four PCs were stolen the year before and they had not been replaced. The school had internet access in the ICT laboratory for the computer studies classes and in the administrative offices. Thandi Sibandla said she had struggled for years to persuade school management of the need to prioritise connectivity in the library.

It was noteworthy that, while a few respondents called for a "full-time qualified librarian”, none made any mention of Lindi Maropa, The Bookery assistant.

The underuse of the library by teachers and the standing of the library in the school were two strong themes running through the interviews with Lindi Maropa and the teacherlibrarian Thandi Sibandla. The two had interestingly different perspectives. In this interview extract, Thandi Sibandla, referred to the prevailing teaching styles - in which the library was something "extra":

Not everybody sees the value because they are too busy in the classroom. For them library is an extra thing. Whereas in reality you should be incorporating it into learning. It's like the library does its own thing and then the school functions - whereas we should actually work together.

In an interview, Lindi Maropa echoed the teachers' views on the need for more and better resources and for internet access. She appealed for:

... more support from the teachers ..., if we could get the Internet and computers. And get more books that are relevant to learners. Not just only non-fiction, but also fiction. And get more Xhosa books, because it starts in the mother language ... 
But in a later conversation she suggested another more sensitive factor, that of Thandi Sibandla's "territorialism". In this extract, Lindi claimed that some teachers saw her and as belonging to Thandi and so tended to keep away:

Because I am always with her [Thandi], I work with her, and then maybe some teachers don't like her. So they don't like the idea of the library because she takes ownership of it, she is very protective of the library. She is very territorial.

Thandi Sibandla was certainly aware of staffroom politics and of gendered power relations, as evidenced in the interview when she explicitly acknowledged how she often used a senior male teacher as her "ace card", "to go and influence the other guys". She talked of her irritation at having to "manipulate and beg and grovel and play nice, you know, just to get the library going".

The case of the NSS library holds many lessons for The Bookery management and for the huge project of building effective school library systems across the country. Perhaps the most important is the awareness it brings that "giving" a library to a school is only the first step. The engagement over a few weeks in the working life of Naledi Maloto and Thandi Sibandla revealed the complex interactions and negotiations involved in their attempts to cement the library into the life of the school. Hopefully, this account has lent support to Williamson's $(2006,98)$ claim that the strength of participant observation is that it allows the "complexities of the real world" to emerge.

\section{Strengths and challenges of participant observation}

Together, the three studies described in the article show how deeply held beliefs about libraries and conceptions of their social role might explain the gaps between the lipservice paid to the importance of libraries and behaviours on the ground. In keeping with one of the principles of interpretive research, the interplay of observations and iterative interviewing enabled the researcher to dig beneath the surface (Klein and Myers 1999, 77).

The preceding discussion has provided evidence in support of the power of the participant observation methodology to dig beneath the surface of the three research sites. The researcher's immersion in a situation and the "following your nose" approach that goes with participant observation builds rich understanding of a specific case. This then throws light on existing theory and other contexts. As Flyvbjerg $(2006,222)$ points out, knowledge is built from many cases: "Context-dependent knowledge and experience are at the very heart of expert activity. Such knowledge and expertise also lie at the centre of the case study as a research and teaching method".

Each of the three studies brought surprises; their progressive and accumulative data analysis led to new understandings and interpretations. The three accounts aimed at showing the "complex interactions, tacit processes and hidden beliefs and values" (Marshall and Rossman 1995, 9) that exist at the three research sites - which are probably at 
play in other contexts and which have to be taken into account in planning effective library and information literacy programmes in South African schools and libraries.

However, the article has also provided evidence of the perils of participant observation - which are inseparable from its strengths. Some of the perils are logistical. Participant observation is time-consuming and expensive. Qualitative researchers warn of the "alarming" volumes of data that are accumulated - much of which might not be relevant to the research problem under investigation (Richards 2009, 33, 58). They also warn of the difficulties in writing up qualitative studies. How does the researcher condense a study for a journal article when the descriptions, analyses, and interpretations are so rich and overlaid and nuanced?

However, the more significant perils are ethical. These relate to the researcher's positioning - and the power relations between the researcher as observer and the participants. The researcher's role - however "native" he/she might believe he/she goes - is inevitably based on relationships of control and hierarchy. As Morrison, Gregory and Thibodeau (2015) warn, participants might well feel exploited once the researcher has departed. The "complex interactions and tacit processes" being explored often involve sensitive relations - as, for example, those between the two Woodsville librarians.

A strand of discussion in the research literature deals with the issue of researcher honesty and disclosure in participant observation (e.g. Berg 2007, 186; Labaree 2002; Neuman 2006, 412; Punch 1994). Ethnography, with its long-term and progressive data collection techniques, might well involve some lies or half-truths. There were, for example, several ethical challenges in the course of the Galant study. In the beginning, in order to gain access and acceptance and knowing that many teachers dislike being observed in the classroom and that they often get their classes to "perform" for visitors, I described my research interest rather vaguely as "information literacy and the new curriculum". Although this was not a lie, it hid, perhaps, the full truth that the focus was inevitably to be on the teachers' classroom techniques. In my defence, it has to be said that the need for this sharp focus only became apparent once the project work observation was under way. Punch (1994, 91) argues that some dissimulation is inevitable in research fieldwork and suggests that researchers be pragmatic and recognise the consequences for the subjects and for themselves when weighing up the pros and cons of total openness: "I base this position on the view that subjects should not be harmed but also the pragmatic perspective that some dissemination is intrinsic to social life and, therefore, also to fieldwork."

\section{Conclusion}

While acknowledging its practical and ethical challenges, the account of participant observation in the article has tried to demonstrate its value over the superficial qualitative case studies that, on the basis of a visit and once-off interviews, make definitive conclusions about a site and its participants. Hopefully, the article has illustrated the strengths of participant observation in terms of the principles of interpretive research which were quoted earlier, namely: 
- An understanding of a whole comes from an understanding of its parts and of how they interrelate with one another and with the whole. The "big picture" of each of the three sites is constructed from the issues and themes that emerged from the data gathering.

- Each of the three studies was grounded in its own context - shown to be crucial to understanding what was happening. For example, a knowledge of the poverty- ridden environment of Galant Primary is essential in making sense of the issues and themes that arose there.

- Researchers have to acknowledge their impact on participants and, as in the course of all three projects, also be ready to have their own preconceived notions challenged. Thus, my understanding of the teaching I observed at Galant Primary shifted as my insight into the teachers' strategies to cope with change grew more nuanced.

- Multiple and equally truthful interpretations of events and situations are quite possible - as shown in the differing perspectives of Tara Botha and Naledi Matolo in the Woodsville study.

- Researchers should constantly look beyond the surface detail, and dig deeper to discover the power structures and possible inequalities - which were revealed in the Woodsville and NSS studies.

Stake's $(1995,240)$ description of the powerful subtlety of participant observation case studies serves to conclude my argument: "[In participant observation] ... ideas are structured, highlighted, subordinated, connected, embedded in contexts, laced with flavour and doubt." 


\section{References}

Berg, B. L. 2007. Qualitative Research Methods for the Social Sciences. Sixth edition. Boston: Pearson.

Creswell, J. W. 2007. Qualitative Inquiry and Research Design: Choosing Among Five Approaches.

Thousand Oaks: Sage.

DAC (Department of Arts and Culture) and NCLIS (National Council for Library and Information Services). 2014. The Library and Information Services (LIS) Transformation Charter. http://www.nlsa.ac.za/ Downloads_01/2014_Final_LIS_Transformation_Charter.pdf (accessed April 9, 2017).

DBE (Department of Basic Education). 2012. National Curriculum Assessment Policy Statements (NCS) Grades R $R-12$. http://www.gov.za/sites/www.gov.za/files/37081_rg10067_gon920.pdf (accessed April 2, 2017).

DBE (Department of Basic Education). 2013. South African Schools Act, 1996 (No. 84 of 1996). Regulations and Standards for Public School Infrastructure. https://www. s.gov.za/Content/Files/SchoolsAct.pdf

DBE (Department of Basic Education). 2017. National Curriculum Statements (NCS) Grades $R-12$. http://

www.education.gov.za/Curriculum/NationalCurriculumStatementsGradesR-12.aspx (accessed April 2, 2017).

De Vries, L. 2002. Die Beskikbaarheid, Voorsiening en Benutting van Skoolbiblioteekfasiliteite Binne 'n Uitkomgebaseerde Onderwysbedeling in die Noord-Kaap Provinsie. MEd dissertation, University of the Free State. http://scholar.ufs.ac.za:8080/xmlui/handle/1166o/2249?show=full (accessed April 9, 2017).

Delamont, S., and D. Hamilton. 1984. Revising Classroom Research: A Continuing Cautionary Tale. In Readings on Interaction in the Classroom, edited by S. Delamont, 3-28. London: Methuen.

DoE (Department of Education). 1997. Curriculum 2005: Lifelong Learning for the $21^{\text {st }}$ Century. Pretoria: DoE.

DoE (Department of Education). 2002. Revised National Curriculum Statement Grades $R-9$ (Schools). Overview. http://www.education.gov.za/Portals/o/CD/GET/doc/overview. pdf?ver=2006-11-21-100143-00o (accessed April 2, 2017). 
Equal Education. 2012. Equal Education Launches Court Case Against Minister for Basic $\begin{array}{llll}\text { Education, Angie Motshekga. } & \text { March } & \text { 7, }\end{array}$ http://www.equaleducation.org.za/article/equal-education-launches-

court-case-against-minister-for-basic-education-angie-motshekga (accessed October 29, 2014).

Flyvbjerg, B. 2006. Five Misunderstandings About Case Study Research. Qualitative Inquiry 12 (2): 219- 245. https://doi.org/10.1177/1077800405284363

Guest, G, E. E. Namey, and M. L. Mitchell. 2012. Collecting Qualitative Data. Thousand Oaks: Sage.

Hart, G. 1999. Information Literacy Education in Disadvantaged Schools. A Case Study of Project Work at a Primary School in South Africa. School Libraries Worldwide 5 (1): 78-96.

Hart, G. 2004. The Readiness of Public Libraries in South Africa for Information Literacy Education. The Case of Mpumalanga Province. PhD dissertation, University of Cape Town.

Hart, G. 2006a. Educators and Public Librarians: Unwitting Partners in the Information Literacy Education of South African Youth? Innovation 32: 74-94. https://doi.org/10.4314/innovation.v32i1.26514

Hart, G. 2006b. The Information Literacy Education Readiness of Public Libraries in Mpumalanga Province (South Africa). Libri 56 (1): 48-62. https://doi.org/10.1515/LIBR.2006.48

Hart, G. 2015. A Study of The Bookery's Library Assistants Programme in Cape Town: A Way Forward for the Staffing of School Libraries in South Africa and Other Developing Countries? In The School Library Rocks: Proceedings of the 44th International Association of School Librarianship (IASL) Conference 2015, Incorporating the 19th International Research Forum. Volume II: Research Papers, edited by L. H. Das, S. BrandGruwel, J. Walhout and K. Kok, 244-258. Second updated edition. Heerlen: Open Universiteit. http://www.meles.nl/_clientfiles/SMD/IASL2015_Proceedings_ Vol2_2ndEd_ResearchPapers.pdf\#page=246 (accessed April 9, 2017).

Hart, G., and S. Zinn, S. 2007. The Conundrum of School Libraries in South Africa. In Libraries for the Libraries, edited by T. Bothma, P. Underwood and P. Ngulube, 89-107. Pretoria: Library and Information Association of South Africa.

Hart, G., and S. Zinn. 2015. The Drive for School Libraries in South Africa: Intersections and Conne Library Trends 64 (1): 19-40. https://doi.org/10.1353/lib.2015.0035 
Klein, H. K., and M. D. Myers. 1999. A Set of Principles for Conducting and Evaluating Interpretive Field Studies in Information Systems. MIS Quarterly 23 (1): 67-94. https://doi.org/10.2307/249410

Labaree, R. V. 2002. The Risk of 'Going Observationalist': Negotiating the Hidden Dilemmas of Being an Insider Participant Observer. Qualitative Research 2 (1): 97-122. https://doi.org/10.1177/1468794102002001641

Marshall, C., and G. B. Rossman. 1995. Designing Qualitative Research. Second edition. Thousand Oaks: Sage.

Morrison, Z. J., D. Gregory, and S. Thibodeau. 2012. “Thanks for Using Me': An Exploration of Exit Strategy in Qualitative Research.” Journal of Qualitative Methods 11 (4): 416-427. https://doi. org/10.1177/160940691201100408

Neuman, W. L. 2006. Social Research Methods: Qualitative and Quantitative Approaches. Sixth edition. Boston: Pearson.

Pashia, A., and J. Critten. 2015. Ethnography as Pedagogy in Library Orientations. Journal of Information Literacy 9 (2): 84-93. http://dx.doi.org/10.11645/9.2.2028

Punch, M. 1994. Politics and Ethics in Qualitative Research. In Handbook of Qualitative Research, edited by N. K. Denzin and Y. S. Lincoln, 83-97. Thousand Oaks: Sage.

Richards, L. 2009. Handling Qualitative Data: A Practical Guide. Second edition. Los Angeles: Sage. Stake, R. E. 1995. The Art of Case Study Research. Thousand Oaks: Sage. Williamson, K. 2006. Research in Constructivist Frameworks using Ethnographic Techniques. Library Trends 55 (1): 83-101. https://doi.org/10.1353/lib.2006.0054

Wolcott, H F. 1994. Transforming Qualitative Data: Description, Analysis, and Interpretation. Thousand Oaks: Sage.

Wolcott, H F. 1992. Posturing in qualitative inquiry. In The Handbook of Qualitative Research in Education, edited by W. LeCompte, W. L. Millroy and J. Preissle, 3-52. San Diego: Academic Press.

Zinn, S. 2002. Information Literacy Skills: A National Perspective. In Education Library Information and Technology Services. Ghost Libraries and Curriculum 2005: Proceedings of 1st Annual Provincial e, Durban, July 11-13, 6-13. Durban: ELITS, Department of Education and Culture, KwaZulu-Natal. 